\title{
The Effects of Orally Administered Linoleic Acid and Its Autoxidation Products on Intestinal Mucosa in Rat
}

\author{
Kazuki KanaZawa, ${ }^{1}$ Hitoshi Ashida, ${ }^{2}$ Shinsuke Minamoto, ${ }^{2}$ \\ Gen-ichi DANNO, ${ }^{1}$ and Masato NATAKE ${ }^{1}$ \\ ${ }^{1}$ Department of Agricultural Chemistry and ${ }^{2}$ Division of Utilization \\ of Biological Resources, Kobe University, Nada-ku, Kobe, \\ Hyogo 657, Japan
}

(Received February 12, 1988)

\begin{abstract}
Summary Linoleic acid and its autoxidation products, hydroperoxides and their secondary products, were orally administered to rats $(350 \mathrm{mg}$ each/rat). Hemorrhage was seen in the alimentary canal at $6 \mathrm{~h}$ after the dose of hydroperoxides. To examine their toxicities on intestinal mucosa, the activities of mucous enzymes (sucrase, maltase, and alkaline phosphatase) were measured. Hydroperoxides and their secondary products decreased the enzyme activities in jejunum at $6 \mathrm{~h}$ after the doses and increased them in both jejunum and ileum at $15 \mathrm{~h}$, as compared to linoleic acid or saline solution. The decrease of enzyme activity was marked in the hydroperoxide group and the increase was marked in the secondary product group. Then, in in vitro experiments, the effects of autoxidation products on these enzymes were determined. Autoxidation products inactivated only alkaline phosphatase. Thus, the results in vivo disagreed with those in vitro. It was assumed that autoxidation products orally administered attacked a membrane of intestinal microvilli whereas in vitro they directly affected the enzymes.
\end{abstract}

Key Words autoxidation products, lipid peroxide, linoleic acid hydroperoxide, oral administration, small intestine, mucous enzyme, sucrase, alkaline phosphatase, maltase

Autoxidation products of polyunsaturated fatty acids occur in our daily food, though their amounts may not always be high. Autoxidation products suppress rat growth and produce necrotic organs and tissues when administered orally (1-3). We have nutritionally clarified the hepatotoxicity of autoxidation products in rats (410). A part of the secondary autoxidation products orally administered was incorporated into the liver $(4,6)$. It impaired the activity of hexokinase and

${ }^{1}$ 金沢和樹, ${ }^{2}$ 芦田 均, ${ }^{2}$ 源 伸介, ${ }^{1}$ 団野源一, ${ }^{1}$ 名武昌人 
phosphoglucomutase (8), and led to a reduction in the NADPH level in the liver (9). It later affected the lipid metabolism during detoxification (7). This hepatotoxicity is probably due to aldehyde species present in the secondary products $(5,10,11)$.

Autoxidation products orally administered pass through the alimentary canal before being incorporated into the liver. Their deleterious effects on the intestines must also be noted. Autoxidation products can be classified into hydroperoxides (primary product) and their secondary products. Secondary products are a mixture of polymers, endoperoxides, and aldehydes. It has formerly been believed that most hydroperoxides are readily decomposed or reduced to hydroxy derivatives in the digestive tract within several hours $(12,13)$. However, a more recent study reports that part of the secondary products incorporated into the liver are unchanged in their forms (6).

The fate of secondary products in the gastrointestinal lumen is made clear by the tracer experiments $(4,14)$. When the radioactive secondary products were orally administered, radioactivity in the stomach quickly decreased and it increased in small intestines with time. The latter reached a maximum at $6 \mathrm{~h}$ after the administration and remained at a high level until $24 \mathrm{~h}$. Thus, the toxicity of hydroperoxides on the alimentary canal may be different from that of secondary products.

In the present study, autoxidized linoleic acid was chromatographically separated into linoleic acid, its hydroperoxides and their secondary products. They were orally administered to rats. The small intestines were taken out $6 \mathrm{~h}$ and $15 \mathrm{~h}$ after the administration. The intestinal enzymes sucrase and maltase are believed to distribute to the outer membrane of the microvilli of epithelial cell and alkaline phosphatase to the inner membrane of the cell (15). It is generally considered that these enzyme activities can reflect the representative integrity and function of the brush border membrane (16). Then, these enzyme activities were measured.

\section{MATERIALS AND METHODS}

Autoxidation products. Linoleic acid was purchased from Tokyo Kasei Kogyo Co., Ltd. and autoxidized at $37^{\circ} \mathrm{C}$ for 7 days. Linoleic acid, linoleic acid hydroperoxides and their secondary autoxidation products were obtained from the autoxidized linoleic acid by silica gel column and thin-layer chromatographies (17). The purity of linoleic acid and linoleic acid hydroperoxides were $>95 \%$ and $>89 \%$, respectively. The secondary product fraction was analyzed by gas chromatographymass spectrometry and Sephadex LH-20 gel filtration-chromatography (18). The secondary product fraction consisted of $36 \%$ mixture of polymers, $26 \%$ epoxyhydroperoxides or endoperoxides, $4.8 \%$ 9-oxononanoic acid, $3.7 \%$ hexanal, $2.5 \%$ nonanedioic acid, $2.4 \%$ short chain carboxylic acids, $0.75 \%$-oxooctanoic acid, $0.34 \% 12$-oxododecadienoic acid, and other smaller unidentified compounds.

Authentic chemicals were used in in vitro experiments. 9-Oxononanoic acid was synthesized from oleic acid by oxidation and purified (5). Commercial nonanedioic 
acid was recrystallized with hot water. Methyl-esterification of the autoxidation products was carried out by diazomethane gas.

Animals and diet. Male Wistar rats, 5 weeks old and each weighing about $110 \mathrm{~g}$ (KY, SPF: Shizuoka Laboratory Animal Center), were housed at $23^{\circ} \mathrm{C}$ with a light and dark cycle of $12 \mathrm{~h}$ each, and fed with a fresh diet for 1 week. The diet was prepared daily and its peroxide value was maintained at less than $0.5 \mathrm{meq} / \mathrm{kg}$. The details of the diet composition have been described previously(4). Briefly, it consisted of $30 \%$ sucrose, $25 \%$ casein, $24 \%$ corn starch, $15 \%$ soybean $4 \%$ McCollum's salt mixture, $1 \%$ cellulose powder, and 1\% vitamin mixture. Food was withheld for $4 \mathrm{~h}$ and the rats were divided at random into 4 groups of 8 rats each. These groups of rats were intragastrically given $350 \mathrm{mg} / \mathrm{rat}$ of linoleic acid, linoleic acid hydroperoxides, secondary products, or saline solution, respectively, using a tuberculin syringe equipped with a stomach tube.

Enzyme activity. Four rats of each group were sacrificed at $6 \mathrm{~h}$ after the administrations and the other 4 rats of each group at $15 \mathrm{~h}$. The animals were rendered unconscious, decapitated and then abdominally opened. Small intestines (from the ligament of Treitz up to the ileocecal valve) were immediately taken out and the mesenterium and duodenum were removed from the intestines. The intestines were cut into halves. The part near to the duodenum was used as jejunum and the other half was used as ileum. These tracts were opened with scissors, washed with saline solution 3 times, and blotted with a filter paper. Intestinal mucosa was scraped from them with a cover glass. The mucosa was homogenized with 10 volumes of saline solution using a Potter-type homogenizer. The homogenate was subjected to measurements of enzyme activities after dilution to an optimal concentration. Sucrase and maltase activities were determined by production of glucose according to the method of Dahlqvist (19). Sucrose or maltose was added to the homogenate and incubated at $37^{\circ} \mathrm{C}$ for $1 \mathrm{~h}$. The enzyme reaction was stopped by heating and the reaction mixture was centrifuged $3,000 \times g$ for $10 \mathrm{~min}$. The glucose amount in the supernatant was measured using glucose oxidase (20). The activity of alkaline phosphatase was assayed by the determination of phenol produced from phenylphosphate as a substrate (21). The protein content in the homogenate was determined by the method of Lowry (22).

Statistical analysis. The data were analyzed statistically to calculate the SEM. The Student's $t$-test was used and a 0.05 probability level was chosen to determine the significant difference.

Observation of the effects of autoxidation products on the mucous membrane enzymes in in vitro experiments. Untreated rat was sacrificed and the intestinal mucosa was collected from jejunum as described above. The mucosa was homogenized with 20 volumes of saline solution and further diluted to 20 times before use. The diluted solution contained around $0.3 \mathrm{mg}$ of protein $/ \mathrm{ml}$. The solution had $15 \mu \mathrm{mol} / \mathrm{min} / \mathrm{ml}$ of sucrase activity, $3.0 \mu \mathrm{mol} / \mathrm{min} / \mathrm{ml}$ of maltase, and $0.37 \mu \mathrm{mol} / \mathrm{min} / \mathrm{ml}$ of alkaline phosphatase. One milliliter of the solution was incubated at $37^{\circ} \mathrm{C}$ with $0.1 \mathrm{ml}$ of ethanol or ethanol solution containing $200 \mu \mathrm{g}$ each 
of linoleic acid, its hydroperoxides, and their secondary products, 9-oxononanoic acid, nonanedioic acid, or their methyl esters. The mixtures were subjected to extraction with $3 \mathrm{ml}$ of diethyl ether 3 times to remove the autoxidation products at each interval of the incubations $(0,10,20,30,45$, and $60 \mathrm{~min})$. For a part of the solution, the enzymic analyses were performed in triplicate $(50 \mu \mathrm{l} \mathrm{each})$. The remaining activity of the enzyme in the solution was calculated.

\section{RESULTS}

Linoleic acid, its hydroperoxides and their secondary autoxidation products were administered intragastrically. Their effects on the alimentary canals were observed macroscopically $6 \mathrm{~h}$ after the doses. Hemorrhage and necrosis were not seen in the groups administered with linoleic acid and the secondary products, as well as in the control (saline) group. Hydroperoxides, however, produced diarrhea and slight hemorrhage in the alimentary canals (stomach, duodenum, jejunum, ileum, cecum, colon, and rectum). A small dose of hydroperoxides ( $200 \mathrm{mg} / \mathrm{rat}$, or less) did not lead to these stresses but a large dose did (500 mg/rat or more), as described by Holman and Greenberg(23). Thus, hydroperoxides orally administered indicated an acute toxicity in the animals.

Then, to examine the toxicities of hydroperoxides and the secondary products on the intestines, the small intestine was taken out $6 \mathrm{~h}$ and $15 \mathrm{~h}$ after the doses and divided into two equal pieces after the duodenum had been removed. It is generally known that the rodent small intestine is mainly composed of jejunum and ileum. Therefore, we used the half near to the duodenum as jejunum and the other half as ileum. The enzyme activities of sucrase (Table 1), maltase (Table 2), and alkaline phosphatase (Table 3) in the intestinal mucosa were determined. These enzyme activities in both jejunum and ileum remained unchanged by the dose of linoleic acid, as compared with that in the control group. Then, the effects of hy-

Table 1. Effects of orally administered autoxidation products on sucrase activity of the intestinal mucosa.

\begin{tabular}{ccccc}
\hline Saline & $\begin{array}{c}\text { Linoleic } \\
\text { acid } \\
\end{array}$ & $\begin{array}{c}\text { Hydroperoxides } \\
(\mathrm{nmol} / \mathrm{min} \text { per mg protein })\end{array}$ & $\begin{array}{c}\text { Secondary } \\
\text { products }\end{array}$ \\
\hline \multicolumn{2}{l}{ 6h after administrations } \\
in jejunum & $0.512 \pm 0.041$ & $0.492 \pm 0.040$ & $0.278 \pm 0.031^{*}$ & $0.379 \pm 0.036^{*}$ \\
in ileum & $0.203 \pm 0.017$ & $0.183 \pm 0.013$ & $0.176 \pm 0.011$ & $0.213 \pm 0.035$ \\
15 h after administrations & & & \\
in jejunum & $0.520 \pm 0.039$ & $0.547 \pm 0.041$ & $0.797 \pm 0.072^{*}$ & $0.649 \pm 0.043^{*}$ \\
in ileum & $0.218 \pm 0.016$ & $0.178 \pm 0.034$ & $0.138 \pm 0.010^{*}$ & $0.491 \pm 0.023^{*}$ \\
\hline
\end{tabular}

* Significant difference from the corresponding saline group. 
droperoxides and the secondary products were compared to that of linoleic acid.

The sucrase activity in the jejunum was significantly decreased by $45 \%$ and $25 \%$ in the hydroperoxides and the secondary product groups, respectively, at $6 \mathrm{~h}$ after the doses (Table 1); the sucrase activity of ileum did not change by their administrations. At $15 \mathrm{~h}$ after the dose, in the hydroperoxide group, the activity was increased by $50 \%$ in jejunum and decreased by $40 \%$ in ileum. In the secondary product group, $25 \%$ and $125 \%$ increases in the activity were observed in jejunum and ileum, respectively. Thus, the sucrase activity was decreased at the early period after the doses of autoxidation products, and later the activity was increased mostly in jejunum.

Table 2 shows the activity of maltase. The maltase activities in the jejunum $(15 \%)$ and ileum $(45 \%)$ were decreased at $6 \mathrm{~h}$ in the hydroperoxide group, but did not change in the secondary product group. The activities $15 \mathrm{~h}$ after the doses, were

Table 2. Effects of orally administered autoxidation products on maltase activity of the intestinal mucosa.

\begin{tabular}{|c|c|c|c|c|}
\hline & Saline & \multicolumn{2}{|c|}{$(\mathrm{nmol} / \mathrm{min}$ per $\mathrm{mg}$ protein) } & $\begin{array}{l}\text { Secondary } \\
\text { products } \\
\text { in) }\end{array}$ \\
\hline $\begin{array}{l}6 \mathrm{~h} \text { after admi } \\
\text { in jejunum } \\
\text { in ileum }\end{array}$ & $\begin{array}{l}\text { trations } \\
0.652 \pm 0.033 \\
0.648 \pm 0.038\end{array}$ & $\begin{array}{l}0.648 \pm 0.038 \\
0.419 \pm 0.021\end{array}$ & $\begin{array}{l}0.559 \pm 0.019^{*} \\
0.354 \pm 0.016^{*}\end{array}$ & $\begin{array}{l}0.635 \pm 0.017 \\
0.484 \pm 0.024\end{array}$ \\
\hline $\begin{array}{l}15 \mathrm{~h} \text { after adm } \\
\text { in jejunum } \\
\text { in ileum }\end{array}$ & $\begin{array}{l}\text { istrations } \\
0.656 \pm 0.054 \\
0.462 \pm 0.043\end{array}$ & $\begin{array}{l}0.695 \pm 0.034 \\
0.477 \pm 0.031\end{array}$ & $\begin{array}{l}0.884 \pm 0.045^{*} \\
0.533 \pm 0.032\end{array}$ & $\begin{array}{l}0.839 \pm 0.046^{*} \\
0.700 \pm 0.074^{*}\end{array}$ \\
\hline
\end{tabular}

* Significant difference from the corresponding saline group.

Table 3. Effects of orally administered autoxidation products on alkaline phosphatase activity of the intestinal mucosa.

\begin{tabular}{|c|c|c|c|c|}
\hline & Saline & $\begin{array}{l}\text { Linoleic } \\
\text { acid }\end{array}$ & $\begin{array}{l}\text { Hydroperoxides } \\
\text { 1/min per mg pro }\end{array}$ & $\begin{array}{l}\text { Secondary } \\
\text { products }\end{array}$ \\
\hline $\begin{array}{l}6 \mathrm{~h} \text { after adm } \\
\text { in jejunum } \\
\text { in ileum }\end{array}$ & $\begin{array}{l}\text { rations } \\
22.9 \pm 1.1 \\
5.78 \pm 0.42\end{array}$ & $\begin{array}{l}20.7 \pm 1.6 \\
5.11 \pm 0.57\end{array}$ & $\begin{array}{l}16.9 \pm 1.8^{*} \\
6.95 \pm 0.68\end{array}$ & $\begin{array}{l}16.6 \pm 0.7^{*} \\
5.75 \pm 0.39\end{array}$ \\
\hline $\begin{array}{l}15 \mathrm{~h} \text { after adn } \\
\text { in jejunum } \\
\text { in ileum }\end{array}$ & $\begin{array}{l}\text { strations } \\
22.5 \pm 1.6 \\
6.03 \pm 0.68\end{array}$ & $\begin{array}{l}22.1 \pm 0.8 \\
6.34 \pm 0.56\end{array}$ & $\begin{array}{l}20.5 \pm 0.3 \\
7.88 \pm 0.35\end{array}$ & $\begin{array}{l}27.5 \pm 1.2^{*} \\
13.0 \pm 1.5^{*}\end{array}$ \\
\hline
\end{tabular}

* Significant difference from the corresponding saline group. 
increased in jejunum of the hydroperoxide group (35\%), and in jejunum $(30 \%)$, and ileum $(50 \%)$ of the secondary product group.

Table 3 shows the changes in the alkaline phosphatase activity. The activities were decreased by $25 \%$ in jejunum at $6 \mathrm{~h}$ in both groups of hydroperoxides and the secondary products, but remained constant in ileum. On the contrary, $15 \mathrm{~h}$ after the dose, the activities of jejunum and ileum in the secondary product group were increased to $120 \%$ and $200 \%$, respectively. Thus, the activities of these three intestinal enzymes were significantly increased $15 \mathrm{~h}$ after the doses, especially in the secondary product group.

The effects of the autoxidation products on the mucous enzymes were examined in in vitro experiments (Figs. 1-3). The mucosa of jejunum of untreated rat was homogenized. The homogenate was incubated with the methyl-esterified products of linoleic acid, hydroperoxides and the secondary products. The activities of sucrase, maltase, and alkaline phosphatase were determined in relation to the incubation time. Figure 1 shows the remaining activities of sucrase and maltase after the incubations. Autoxidation products very slightly decreased the sucrase activity, and similar results were obtained with the non-esterified products (data not shown).

Figure 2 shows the toxic effects of the autoxidation products on alkaline phosphatase activity. Linoleic acid decreased the activity by $50 \%$ at the early period of incubation, but the activity completely recovered $60 \mathrm{~min}$ after the incubation. Hydroperoxides and the secondary products decreased the activity to $40 \%$ without

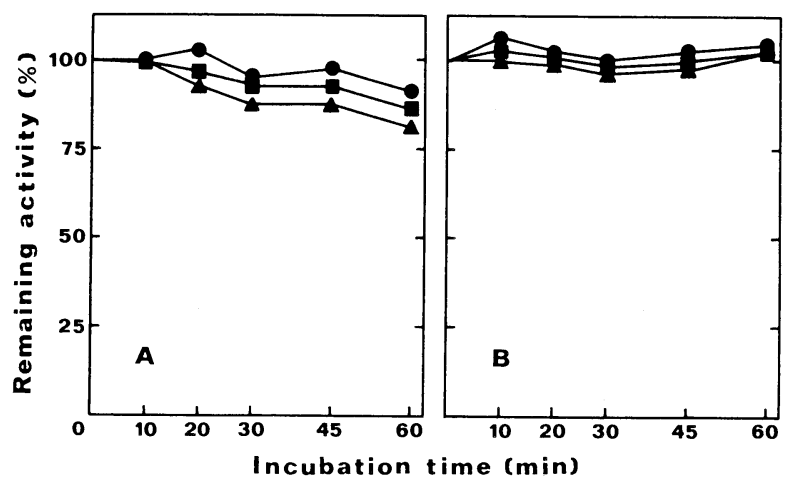

Fig. 1. The effects of the autoxidation products on the enzyme activities of sucrase (A) and maltase (B) in vitro. The homogenate of intestinal mucosa of untreated rat was incubated at $37^{\circ} \mathrm{C}$ with $200 \mu \mathrm{g}$ each $/ \mathrm{ml}$ of methyl linoleate (O), methyl linoleate hydroperoxides $(\boldsymbol{\square})$, or methyl-esterified secondary products $(\boldsymbol{\Delta})$. The incubation mixtures were washed to remove the autoxidation products at each interval of the incubation $(0,10,20,30,45$, and $60 \mathrm{~min})$, and the enzyme activities were assayed. The activity of a control solution, which was incubated with alcohol, was taken as 100. The activity at each incubation time was expressed as the remaining activities $(\%)$. 
subsequent recovery. These chemicals were methyl-esterified and then incubated with the homogenate. The toxicity of linoleic acid was weakened by the methylesterification and the toxicity of hydroperoxides was slightly weakened. The toxicity

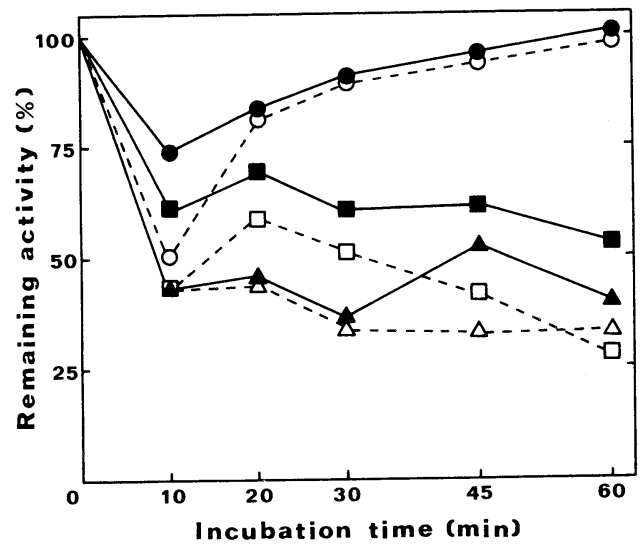

Fig. 2. The effects of the autoxidation products on the alkaline phosphatase activity in vitro. The homogenate of intestinal mucosa was incubated at $37^{\circ} \mathrm{C}$ with $200 \mu \mathrm{g}$ each $/ \mathrm{ml}$ of linoleic acid $(\bigcirc)$, its hydroperoxides $(\square)$, secondary products $(\triangle)$, and their methyl-esterified products. The enzyme activity was measured and calculated as shown in Fig. 1. The effects of the methyl-esterified products are shown as shaded symbols; effects of the corresponding non-esterified products are shown as open symbols.

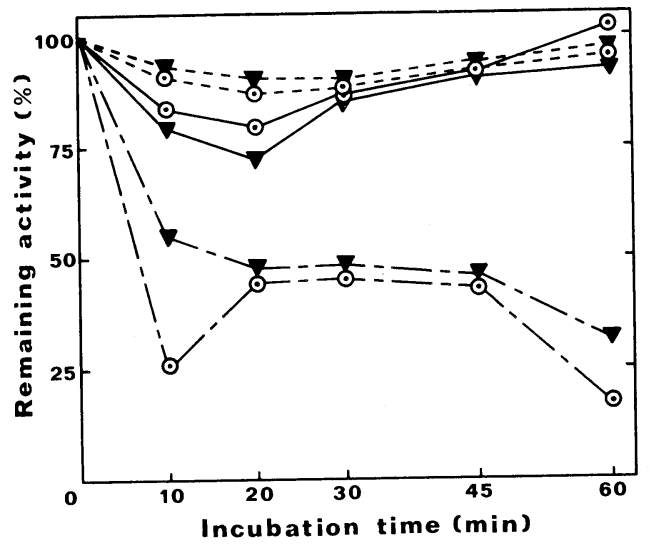

Fig. 3. The effects of methyl esters of 9-oxononanoic acid and nonanedioic acid on the enzyme activity in vitro. The homogenate of intestinal mucosa was incubated at $37^{\circ} \mathrm{C}$ with $200 \mu \mathrm{g}$ each $/ \mathrm{ml}$ of methyl 9-oxononanoate ( $(0)$ and methyl nonanedioate $(\nabla)$. The enzyme activities were determined as shown in Fig. 1. Their effects on sucrase activity are shown by (-), on maltase by (-----), and on alkaline phosphatase by (-- ). Non-esterified 9-oxononanoic acid and nonanedioic acid also produced similar effects on these enzymes. 
of linoleic acid and a part of the toxicity of hydroperoxides might be due to their carboxyl groups. On the other hand, the methyl-esterified secondary products were similar in the effects to the non-esterified products. The effects of methyl-esterified autoxidation products on alkaline phosphatase were in the order of the secondary products $>$ hydroperoxides $>$ linoleic acid. The toxicities of hydroperoxides and the secondary products to alkaline phosphatase might be attributed to peroxide group and the other toxic groups except carboxyl group.

The major component in the secondary products is aldehyde (16). We consider that 9-oxononanoic acid is one of the toxic components $(5,10)$. Figure 3 shows the toxicities on the three enzymes of methyl esters of 9-oxononanoic acid and nonanedioic acid, which is a further oxidized product of 9-oxononanoic acid. They little affected sucrase and maltase, but they easily inactivated alkaline phosphatase. The remaining activity was around $25 \%, 60 \mathrm{~min}$ after the incubations. This result indicates that at least a part of the toxicity of the secondary products is due to 9oxononanoic acid.

\section{DISCUSSION}

The present study demonstrates that the autoxidation products orally administered deleteriously affected the microvilli of rat intestines and that hydroperoxides were a quick-acting toxicant and the secondary products were a slow-acting toxicant.

The activities of three villous enzymes were reduced $6 \mathrm{~h}$ after the intragastric doses of autoxidation products and were increased at $15 \mathrm{~h}$ (Tables 1-3). On the contrary, in in vitro experiments, autoxidation products specifically inactivated alkaline phosphatase (Figs. 1-3). Thus, the results of in vitro experiments disagreed with those in vivo. The discrepancy indicates that a target of autoxidation products when they were orally administered is different from that of in vitro system. Kimura et al.(24) reported that the remarkable release of sucrase from the small intestine was detected on perfusion of the jejunum with buffer containing an oxidized soybean oil. Sucrase and maltase distribute to the outer membrane of microvilli, while alkaline phosphatase is in the inner membrane(15). In vitro, autoxidation products directly affect these enzymes. Alkaline phosphatase was sensitive to their direct attacks. On the other hand, autoxidation products orally administered seem to injure the membrane of intestinal microvilli, but not to attack directly the villous enzymes.

Hydroperoxides are the primary product of autoxidation and their further autoxidized products are the secondary products. The effect of hydroperoxides on the proteins is different from that of the secondary products. We have previously reported on an interaction mechanism of autoxidation products with the protein molecule using casein as a model protein (25). Hydroperoxides were bound to the hydrophobic pockets of casein. The secondary products were bound more easily to both the hydrophobic and hydrophilic positions on the surface of casein than were 
hydroperoxides, because the secondary products are composed of both hydrophobic and hydrophilic aldehydes. Hydroperoxides can be a source of radicals and allow protein polymerization $(26,27)$. The secondary products produce rigid protein, because casein became insoluble, drastically decreasing its digestibility by proteolytic enzymes during the incubation with the secondary products (25).

Hydroperoxides and the secondary products were also different from each other in their effect on the microvillous membrane (Tables 1-3). Autoxidation products decreased the villous enzyme activities $6 \mathrm{~h}$ after the doses. This effect of hydroperoxides was greater than that of the secondary products. Hydroperoxides polymerized the membrane proteins and led to hemorrhage and diarrhea, and subsequently the enzymes were leaked from the membrane. On the contrary, $15 \mathrm{~h}$ after the doses, the enzyme activities were increased. This effect of secondary products was greater than that of the hydroperoxides. Secondary products coated the surface of the membrane proteins and produced the rigid proteins. The membrane permeability decreased and consequently the secretion of the enzymes from an epithelial cell became difficult. The slight leakage of enzymes as the early effect of the secondary products may stimulate production of the enzymes in the epithelial cell and result in the accumulation of enzymes. In the secondary product group, the striking accumulation of alkaline phosphatase was observed at $15 \mathrm{~h}$ after the dose (Table 3). Alkaline phosphatase is synthesized in the epithelial cell. It is deposited in the cell as it migrates up the side of the villus, unlike sucrase and maltase (28). This enzyme may thus easily accumulate in the cell.

A part of hydroperoxides is reduced to nontoxic compound and the others are decomposed to the secondary products with time $(12,13)$. It is surmised that the increases of the enzyme activities $15 \mathrm{~h}$ after the administration of hydroperoxide group is due to the effect of the secondary products formed from hydroperoxides, but not hydroperoxides themselves.

The contents of the digestive tract move from jejunum to ileum with time. The toxicity of hydroperoxides and the secondary products appeared mainly on jejunum $6 \mathrm{~h}$ after the doses; the toxicity of the hydroperoxides was particularly marked (Tables 1-3). Then, $15 \mathrm{~h}$ after the administrations, the toxicity appeared on both jejunum and ileum mainly as the effect of secondary products. It is considered that hydroperoxides are a quick-acting toxicant and the secondary products are slowacting toxicant for the animal intestines. Thus, autoxidation products of linoleic acid act on the intestinal microvilli by two steps, as the toxicity of hydroperoxides and that of the secondary products.

In conclusion, when the diets content a large amount of hydroperoxides, most of them are probably excreted during diarrhea (23). When the amount is low, it is easily decomposed or reduced in the alimentary canal. On the contrary, the secondary products stay for a long time ( $24 \mathrm{~h}$ or more) in the intestines as shown previously with radiochemical experiments (4). The secondary products may chronically affect the intestinal mucosa. In in vitro experiment (Fig. 2), the inactivation of alkaline phosphatase by the secondary products was evidently greater than those by 
hydroperoxides. Therefore, in the animal body also, the secondary products may be more toxic than hydroperoxides. 9-Oxononanoic acid must be one of the toxicants present in the secondary products, as we have asserted $(5,10)$.

\section{REFERENCES}

1) Andrews, J. S., Griffith, W. H., Mead, J. F., and Stein, R. A. (1962): Toxicity of airoxidized soybean oil. J. Nutr., 70, 199-210.

2) Nakamura, M., Tanaka, H., Hattori, Y., and Watanabe, M. (1973): Biological effects of autoxidized safflower oils. Lipids, $\mathbf{8}, 566-572$.

3) Paik, T. H., Hoshino, T., and Kaneda, T. (1976): Histopathological studies on mice administered autoxidized oils (acute toxicity). Nippon Eiyō Shokuryō Gakkaishi (J. Jpn. Soc. Nutr. Food. Sci.), 29, 85-94.

4) Kanazawa, K., Kanazawa, E., and Natake, M. (1985): Uptake of secondary autoxidation products of linoleic acid by the rat. Lipids, 20, 412-419.

5) Minamoto, S., Kanazawa, K., Ashida, H., Danno, G., and Natake, M. (1985): The induction of lipid peroxidation in rat liver by oral intake of 9-oxononanoic acid contained in autoxidized linoleic acid. Agric. Biol. Chem., 49, 2747-2751.

6) Kanazawa, K., and Natake, M. (1986): Identifications of 9-oxononanoic acid and hexanal in liver of rat orally administered with secondary autoxidation products of linoleic acid. Agric. Biol. Chem., 50, 115-120.

7) Kanazawa, K., Ashida, H., Minamoto, S., and Natake, M. (1986): The effect of orally administered secondary autoxidation products of linoleic acid on the activity of detoxifying enzymes in the rat liver. Biochim. Biophys. Acta, 879, 36-43.

8) Ashida, H., Kanazawa, K., Minamoto, S., Danno, G., and Natake, M. (1987): Effect of orally administered secondary autoxidation products of linoleic acid on carbohydrate metabolism in rat liver. Arch. Biochem. Biophys., 259, 114-123.

9) Ashida, H., Kanazawa, K., and Natake, M. (1987): Decrease of the NADPH level in rat liver on oral administration of secondary autoxidation products of linoleic acid. Agric. Biol. Chem., 51, 2951-2957.

10) Minamoto, S., Kanazawa, K., Ashida, H., and Natake, M. (1988): Effect of orally administered 9-oxononanoic acid on lipogenesis in rat liver. Biochim. Biophys. Acta, 958, 199-204.

11) Esterbauer, H., Koller, E., Slee, R. G., and Koster, J. F. (1987): Possible involvement of the lipid-peroxidation product 4-hydroxynonenal in the formation of fluorescent chromolipids. Biochem. J., 239, 405-409.

12) Glavind, J., and Tryding, N. (1960): On the digestion and absorption of lipoperoxides. Acta Physiol. Scand., 49, 97-102.

13) O'Brien, P. J., and Frazer, A. C. (1966): The effect of lipid peroxides on the biochemical constituents of the cell. Proc. Nutr. Soc., 25, 9-18.

14) Oarada, M., Miyazawa, T., and Kaneda, T. (1986): Distribution of ${ }^{14} \mathrm{C}$ after oral administration of $\left[U_{-}{ }^{14} \mathrm{C}\right]$ labeled methyl linoleate hydroperoxides and their secondary oxidation products in rats. Lipids, 21, 150-154.

15) Eichholz, A. (1969): Fractions of the brush border. Fed. Proc., 28, 30-34.

16) Kimura, T., Furuta, H., Matsumoto, Y., and Yoshida, A. (1980): Ameliorating effect of dietary fiber on toxicities of chemicals added to a diet in the rat. J. Nutr., 110, 513-521.

17) Kanazawa, K., Mori, T., and Matsushita, S. (1973): Oxygen absorption at the process of the degradation of linoleic acid hydroperoxides. J. Nutr. Sci. Vitaminol., 19, 263-275. 
18) Kanazawa, K., Danno, G., and Natake, M. (1983): Some analytical observations of autoxidation products of linoleic acid and their thiobarbituric acid reactive substances. Agric. Biol. Chem., 47, 2035-2043.

19) Dahlqvist, A. (1984): $\beta$-Glucosidases (Disaccharidases), in Methods of Enzymatic Analysis, ed. by Bergmeyer, H. U., Bergmeyer, J., and Graßl, M., VCH Verlagsgesellschaft, Weinheim, pp. 208-217.

20) Miwa, I., Okuda, J., Maeda, K., and Okuda, G. (1972): Mutarotase effect on colorimetric determination of blood glucose with $\beta$-D-glucose oxidase. Clin. Chim. Acta, 37, 538-540.

21) Kind, P. P. N., and King, E. J. (1954): Estimation plasma phosphatase by determination of hydrolyzed phenol with aminoantipyrine. J. Clin. Pathol., 7, 322-326.

22) Lowry, O. H., Rosebrough, N. J., Farr, A. L., and Randall, R. J. (1951): Protein measurement with the Folin phenol reagent. J. Biol. Chem., 193, 265-275.

23) Holman, R. T., and Greenberg, S. I. (1958): A note on the toxicities of methyl oleate peroxide and ethyl linoleate peroxide. J. Am. Oil Chem. Soc., 35, 707.

24) Kimura, T., Iida, K., and Takei, Y. (1984): Mechanism of adverse effect of air-oxidized soy bean oil-feeding in rats. J. Nutr. Sci. Vitaminol., 30, 125-133.

25) Kanazawa, K., Ashida, H., and Natake, M. (1987): Autoxidizing process interaction of linoleic acid with casein. J. Food Sic., 52, 475-478.

26) Gamage, P. T., Mori, T., and Matsushita, S. (1973): Mechanism of polymerization of proteins by autoxidized products of linoleic acid. J. Nutr. Sci. Vitaminol., 19, 173-182.

27) Funes, J., and Karel, M. (1981): Free radical polymerization and lipid binding of lysozyme reacted with peroxidizing linoleic acid. Lipids, 16, 347-350.

28) Deren, J. J. (1968): Development of intestinal structure and function, in Handbook of Physiology, section 6: Alimentary Canal, Vol. III. Intestinal absorption, ed. by Heidel, W., American Physiological Society, Washington, D. C., pp. 1099-1118. 